THE BELFAST AGREEMENT AND CROSSBORDER ECONOMIC COOPERATION IN THE TOURISM INDUSTRY

Joan Henderson and Paul Teague 


\title{
THE BELFAST AGREEMENT AND CROSS-BORDER ECONOMIC COOPERATION IN THE TOURISM INDUSTRY
}

\author{
Joan Henderson and Paul Teague
}

Working Papers in British-Irish Studies

No. 54,2006

(also printed as

MFPP working paper no. 4)

Institute for British-Irish Studies

University College Dublin 
IBIS Working Papers

No. 54, 2006

(also printed as

MFPP working paper no. 4)

(C) the authors, 2006

ISSN 1649-0304 


\section{ABSTRACT}

\section{THE BELFAST AGREEMENT AND CROSS-BORDER ECONOMIC COOPERATION IN THE TOURISM INDUSTRY}

This paper examines the impact of the Belfast Agreement on north-south economic cooperation in Ireland, using the tourism industry as a case study. The first part of the paper sets out the suggested benefits that may arise from greater economic and business connections between both parts of the island. It also develops a policy framework which the authors believe is established by the Agreement to achieve these benefits. A number of propositions are developed to assess under what conditions the potential benefits from greater cooperation will actually materialise. The second part of the paper explores the case-study evidence. The paper concludes by arguing that although advances have been made towards greater cooperation, these new initiatives, for the most part, have not been of a deep or strategic kind. The "minimalist" character of strand two of the agreement suggests that no big "institutional push" is likely to emerge to change this situation.

\section{Publication information}

Paper presented at final conference of the Mapping frontiers, plotting pathways: routes to North-South cooperation in a divided island programme, City Hotel, Armagh, 19-20 January 2006.

The programme is funded by the Special EU Programmes Body through the Higher Education Authority over the period 2004-06. 


\section{BIOGRAPHICAL INFORMATION}

Joan Henderson is a lecturer in Management at the School of Management and Economics, The Queen's University Belfast. She holds a PhD from the University of Ulster, Jordanstown. She worked as an engineer for six years before embarking on an academic career. She has recently returned from the University of Waterloo in Ontario where she spent six months as a visiting professor. She has written in the area of policy developments, business improvement and change management. More recently her research has focused on cross-border policy issues and northsouth economic development in Ireland.

Paul Teague is the Martin Naughton Chair of Management at the School of Management and Economics, The Queen's University Belfast. He holds a PhD from the London School of Economics and has been a Fulbright Scholar at the University of Massachusetts. He has written widely on the theme of the employment relations consequences of deeper European integration and the political economy of Ireland, north and south. 



\title{
THE BELFAST AGREEMENT AND CROSS-BORDER ECONOMIC COOPERATION IN THE TOURISM INDUSTRY
}

\author{
Joan Henderson and Paul Teague
}

\section{INTRODUCTION}

Northern Ireland enjoys an imperfect peace. Although a sustainable, widely supported political settlement has yet to be reached, there has been a sharp decline in the level of violence in the region since the (second) IRA ceasefire announced nearly a decade ago. Progress has been made towards developing a political framework for the governance of the region since the signing of the Belfast Agreement in 1998. The Belfast Agreement is an innovative political framework in that it establishes a range of interlocking "internal" and "external" institutions to bring political stability to Northern Ireland (O'Leary, 1999). Three supposedly mutually reinforcing strands were set up by the Agreement. Although strand one of the Agreement, which relates to devolution, has been effectively moth-balled due to a catalogue of political disagreements, the knock-on effects have been limited. Strand two of the Agreement, which established arrangements to promote cross-border cooperation between the two parts of the island and Stand Three, which set up political bodies to foster cooperation between Britain and Ireland, are still operating.

The purpose of this paper is to examine the dynamics of cross-border cooperation, the area covered by Stand Two of the Agreement. The motivation is not to assess the contribution cross-border cooperation has made to the search for a permanent political settlement in the region. Rather it is to investigate the potential and limits to cross-jurisdictional economic policies that transcend established national borders. A common argument is that with the deepening of European integration alongside the rise of networked forms of business activity the relationship between economic and social governance and nation states is no longer co-terminus. As a result regions and nations must forge new cross-jurisdictional institutional connections to promote economic development and solve identified policy problems. Yet the conditions under which these forms of policy collaborations flourish rather than flounder have not been studied closely. This case-study of developing cross-border in the tourism sector in Ireland is an attempt to address this gap in the literature.

The organisation of the paper is as follows. The first section outlines the institutions set up by the Belfast Agreement to develop cross-border cooperation on the island. Then the possible economic benefits that may arise from deeper cross-border collaboration are reviewed. After this assessment, possible policy approaches to crossborder cooperation are explained. The following section sets out the vision behind the institutional arrangements set up by the Belfast Agreement to promote deeper collaboration between the two parts of the island and examines the potential pitfalls that could prevent this vision being realised. The fifth section discusses the economic context and the business dynamics of the tourism industry on the island and 
assess the progress that has been made to forge closer links in the tourist industry in the six years since the signing of the agreement. The penultimate section examines a particular cross-border tourist project in an effort to obtain a deeper understanding of the difficulties and opportunities associated with these types of policy initiatives. The conclusions draw together the arguments developed in the paper.

\section{THE BELFAST AGREEMENT AND NORTH-SOUTH COOPERATION}

The main political decision-making body set up by strand two is the North/South Ministerial Council (NSMC). This body brings together those with executive responsibilities in government each side of the border to "develop consultation, cooperation and action within the island of Ireland". According to the Agreement, it meets twice a year in plenary session, and more regularly on a sectoral basis (education, health etc). The Council is supported by a Standing Joint Secretariat staffed by members of the NI Civil Service and the Irish Civil Service. The main activity of the Council is to develop and supervise work being done in the six institutions and six areas of cooperation set up under the agreement to forge closer connections between the two parts of the island.

The six institutions established by the Belfast Agreement to promote greater northsouth cooperation are known as Implementation Bodies. ${ }^{1}$ Each implementation body is co-funded by the administrations north and south of the border. All have a clear operational remit and are accountable to the NSMC. None can be said to have complete autonomy to agenda-set or determine policy, but some have a degree of freedom to fund research and promote low-level policy innovations. In addition to the Implementation Bodies, the Agreement identified six designated areas of cooperation, transport, agriculture, education, health, environment and tourism. Ministers and officials from the relevant departments in the two administrations on the island determine the form and extent of co-operation in each area jointly. Cooperation in the designated areas of cooperation does not prohibit closer links being developed in other policy spheres.

The active promotion of greater cross-border cooperation is an important departure as it eases the longstanding disagreement between the rival nationalist and unionist political blocs on the matter. Whereas unionists have been cautious about greater cross-border economic and policy connections, nationalists have been enthusiasts (Bradley and Birnie, 2001). These contrasting positions contributed to the political stalemate in the region. By opening up the possibility of more extensive crossborder connections, strand two of the Agreement helps dismantle a barrier to political progress. It also makes the realisation of new all-Ireland business and commercial opportunities a higher level government economic policy objective both in Belfast and Dublin.

\footnotetext{
${ }^{1}$ The six implementation bodies are Waterways Ireland; Safefood; InterTrade Ireland; The Special European Union Programmes Body; The Foyle, Carlingford and Irish Lights Commission; and the North/South Language Body.
} 


\section{POTENTIAL ECONOMIC GAINS FROM NORTH-SOUTH ECONOMIC CO-OPERATION}

On paper, a number of potential benefits could arise from north-south economic cooperation. Greater economies of scale are perhaps the most recognised benefit that may result from forging closer economic interdependence across national borders (Krugman, 1995). These benefits can be captured in a number of ways. Administrative economies can be realised by pooling resources and jointly delivering public services. Communities that straddle the border are likely to be the biggest beneficiaries of this type of collaborative activity. Efficiency dynamics could rise by the market-widening effects of developing all-island economic initiatives. In a more open market environment, certain industries will flourish as previously unexplored business opportunities are exploited. Companies may be encouraged to redesign logistical strategies and treat Ireland as one commercial zone rather than two separate entities. New logistical policies may involve companies changing suppliers, improving the operation of sub-contracting networks, reorganising distribution networks or even moving to a new location. All these changes are likely to have competitiveness boosting effects.

Greater all-island cooperation may promote agglomeration economies or external economies of scale (Michie and Sheehan, 1998). Normally these dynamic effects are external to an individual organisation but internal to the market infrastructure of a particular industry or geographic territory. Financial systems that are in tune with the capital needs of the dominant business activity in a region or a training system that provides a pool of labour with the necessary skills for local companies are examples of agglomeration economies. Social institutions or commercial organisations that are outside but continuously interacting with businesses usually play a pivotal role in the creation and maintenance of these dynamic effects.

A second benefit arising from deeper north-south cooperation is the reduction of market failures. Borders continue to matter in the modern world as they represent the interface between national economic and social systems (McCallum, 1995). Separate national territories create distinctive institutional support structures for economic and social activities. These institutional arrangements are used to resolve bargaining problems that arise in the course of business activity, promote incentives to encourage particular forms of behaviour or strategic action and enhance the flow and processing of information. Thus an overlap exists between national sovereignty and some forms of economic and social activity. The effect is to codify and stabilise business and in certain circumstances deliver other positive externalities. But a potential downside is that markets become fragmented on a territorial or national basis. As a result, borders can increase the transactions costs of doing business across different jurisdictions, thereby giving rise to market failures (Grahl and Teague, 1992).

Market failures can take a number of different forms. One is information asymmetries. Consider decentralised forms of business activity, even in so-called tradable parts of the economy. These markets are characterised by limited information, which tend to result in buyers and sellers not exploring all possible transactions. In- 
stead they maintain a restricted number of commercial deals. Thus decentralised markets often give rise to close and repeated "customer" connections that normally lead to long-term relationships. Decentralised business activity thus becomes socially embedded within distinctive national jurisdictions. This can increase the transactions costs associated with doing business on a cross-border basis: businesses are not aware of market opportunities that they could potentially exploit in another jurisdiction. Another market failure takes the form of a coordination deficit. Different jurisdictions have distinctive governance structures to regulate and manage economic and social activities. These give rise to distinctive rules that embody contrasting social preferences. Thus tax regimes, for example, differ across countries. Contrasting national rules and social preferences make it more difficult to coordinate economic policies across jurisdictions, which can impinge negatively on business activity.

\section{CAPTURING THE GAINS FROM CROSS-BORDER COOPERATION}

Greater cross-border policy coordination is the main way to exploit untapped economies of scale and reduce market failures. Different policy approaches can be used to obtain coordination in the all-island economy. One is the promotion of policy complementarity, which involves public programmes or business activity either side of the border dovetailing better with each other. Policy complementarity seeks to eliminate inefficiencies and boost the valued-added potential of particular parts of the economy (Orszag and Snower, 1998). Policy recombination is another method to deepen all-island economic coordination. The term policy recombination, which is influenced by the evolutionary theory of the firm, describes a process of mutation through which incremental change is made to existing policies both north and south of the border (Nelson and Winter, 1982). This approach encourages new procedures or techniques to be combined with established ways of doing things so that change is brought about gradually to the whole by adjusting the parts. Radical policy departures designed to introduce root-and-branch reform is not envisaged.

Policy entrepreneurship is a third method that could be used to deepen crossborder economic connections. This form of policy is normally experimental in character (Roberts and King, 1996). The motives behind policy entrepreneurship vary. On occasions, the cloak of north-south cooperation may be used to smuggle new policy initiatives onto the domestic policy that might otherwise not see the light of day. On other occasions, the calculation may be more instrumental: cross-border initiatives may be launched to get access to external financial sources. Or the impulse for greater cooperation may be altruistic: greater north-south cooperation may be sought to advance the so-called new political dispensation released by the peace process. Whatever the precise motives, collaborative initiatives of this type are unlikely to be bold and far-reaching precisely because the benefits are not clearcut. Yet they are significant as they can create a snowballing effect, which involves the initial activity generating even further action and so on. 


\section{THE ORGANISING PRINCIPLES OF NORTH-SOUTH COOPERATION}

\section{The vision}

Mapping these policy approaches onto the political arrangements set up by strand two of the Agreement a distinctive institutional profile emerges of how cross-border cooperation is to be fostered. The main purpose of the political arrangements and institutional bodies and procedures created by strand two is to create a supervening policy framework that will act as a "framing centre" to establish stable forms of cooperation and predictable patterns of behaviour amongst those involved in new collaborations (Fung, 2003). The intention is to encourage relevant policy agencies, business organisations and individuals in the two jurisdictions to begin defining the policy questions to explore in a similar fashion and to cast others to one side. Progress is envisaged through creating a broad consensus about acceptable (and unacceptable) types of policy interventions in the context of a fairly open-ended collaborative process in which a range of likely outcomes is possible. In the language of public policy, the "framing centre" is to release an interpretive process focused on the need to define common goals, create a common understanding between participants in co-operation projects and co-ordinate activities necessary to achieve the designated goal (Maarten and Wagenaar-Haher, 2003).

The basal unit for the creation of shared understandings and action plans on crossborder cooperation is the problem-solving team or project. The usual design of these teams is to bring together practitioners or functional specialists to assess the need or scope for a cross-border initiative: it is to create a vision of the most appropriate form of collaboration in a particular area of policy or business activity (Barnard, 1948). The next task is to create a procedural consensus that aims to identify the resources that need to be mobilised and the potential bottlenecks to be addressed so that the agreed initiative is both robust and sustainable. A third task is to monitor the various initiatives to ensure that initiatives are actually performing the tasks they were set up to do, understand why any shortfall in performance is occurring and even assess whether those that are doing well can do better. This monitoring function is particularly important as many north-south initiatives will be new and thus to some extent must be provisional: the capacity to introduce refinements and revisions must be a feature of projects so that continuous adjustments can be made.

Thus the framing centre is not tied to a particular business model for the island but more committed to promoting a myriad of different initiatives and networks, existing inside and outside established public bureaucracies, to advance the goal of northsouth cooperation. Although the emphasis of much north-south cooperation is envisaged to be pragmatic and functional in that the design of projects are likely to be aimed at solving stand-alone problems, the cumulative impact may be far-reaching. On this view, cross-border goal setting, policy co-ordination and mobilisation may trigger a process of interaction, interpretation and internalisation amongst participants (Simon, 1977) that gives rise to a new set of expectations about the possibilities and legitimacy of all-island economic and business activity. A key part of this process will be the creation of credible commitments. Credible commitments are 
important because participants gain an assurance about the behaviour of others but at the same time must provide an assurance about their own behaviour. This is an important dynamic particularly in a context where trust and understanding has been low and engagement underdeveloped. Thus strand two of the Belfast Agreement holds out the possibility of a new economic and business identity emerging on the island of Ireland. At the core of this new identity is the belief that meaningful and purposeful cross-border economic and business activity can be launched that respects existing constitutional frontiers yet works to improve all-island prosperity.

\section{The potential pitfalls}

On paper this is an attractive vision of public policy creating a symbiosis between the north and south of the island on economic matters while the two parts remain constitutionally separate. But creating such a dynamic is a challenging task as designing the institutional framework to develop cross-border cooperation is very difficult. One potential danger is best explained with the use of the principal-agent framework, a core part of the literature on the new economics of the organisation. This framework, sets out to explain why principals (for example governments) delegate policy functions to agents (for example sub-national political entities such as local government or extra-national organisations like the EU or UN) to act on their behalf.

The framework is also used to assess the institutional and policy-making (behavioural) consequences of these decisions. Invariably, the explanation offered as to why government delegates or transfers decision-making or policy-making capabilities to another political level is that without such a move a desired political or economic objective will remain unrealised or a particular problem unsolved: sometimes government has to delegate as certain policy outcomes will remain outside its reach if it acts alone. But adverse consequences may arise if the decision to delegate is not carried out in an effective manner. Thus, for example, if principals delegate too much power to agents, the possibility opens up of the agents acting in a manner that is contrary to the interests of the principals. Alternatively, if the principals delegate too little power to an agent then the agent may be invested with insufficient authority to carry out designated tasks. The message is that a faulty institutional design may cause cross-border initiatives to be distorted in some manner.

A second danger is what Scharpf (1988) calls the joint decision-making trap. Developing meaningful cross-border economic initiatives by definition requires joint decisions to be made by governments with implications for "internal" policy-making systems. Some of these implications may be resource based while others may lead to established programmes being changed. But if policy-makers in either jurisdiction have spent considerable time developing an "internal" initiative they may be reluctant to agree or effectively implement a cross- border programme that could compromise this effort. This scenario is more likely to arise when the calculated (mutual) gains from the north-south initiative are considered to be lower than the transactions costs associated with implementing the joint initiative. In other words, there may be an inbuilt bias towards policy-makers behaving in a solipsistic manner: they are so concerned with holding together policy communities or business networks in their 
respective jurisdictions that they become reluctant to engage in new cross-border activity that cuts across these "domestic" coalitions. This is known as the joint decision-making trap.

A third potential danger is imperfect feedback loops. In systems theory, feedback loops happen when part of an output of some system is connected back into one of its inputs. Feedback loops can either be positive or negative. Whereas a positive feedback loop adds output to the input, a negative feedback lowers input levels. In the policy-making literature, feedback loops are used to denote whether a particular initiative adds to or enhances the prevailing repertoire of policy measures or whether it reduces or diminishes existing programmes. Of course, there is a third possibility which is that a potential feedback loop may not be "closed"-in other words, there are neither positive nor negative returns as the output is not properly connected with the input source. This last option is particularly relevant to the policy context of promoting cross-border cooperation (whether in Ireland or elsewhere).

Joint policy initiatives involving two or more states are frequently set-up as stand alone projects which are not fully integrated into the mainstream policy bureaucracy of either jurisdiction. The danger in this situation is that the policy outcomes from the collaborative initiative may fail to get mainstreamed in one or both states. As a result, the policy outcomes of the joint activity only exist for the life cycle of the project. Cross-border initiatives that are financed by external sources such as the EU are more vulnerable to this predicament as these are not usually connected to mainstream budgetary arrangements.

Thus creating and sustaining cross-border collaboration is a complex task which is sometimes underestimated in the literature. The preceding discussion suggests that we can use three propositions to guide an investigation into whether or not crossborder initiatives reach maximum potential. One is that if delegation between the principals and the agents are not appropriately organised then cross-border initiatives are likely to under perform. Another is that if the mutual gains from crossborder initiatives are not readily apparent or if policy entrepreneurship is low then the outcome may be a joint decision-making trap. Third, policy feedback loops are not likely to be closed if many of the cross-border initiatives are externally funded, "stand alone" projects.

\section{DEVELOPING CROSS-BORDER ECONOMIC CO-OPERATION: A CASE STUDY OF THE TOURISM SECTOR}

Below we examine the tourism sector to assess the nature of the collaborative relationships between agencies, business organisations and individuals in the two jurisdictions, six years after the signing of the Belfast Agreement. This sector was selected as it was considered a relatively non-contentious area of economic activity on which there appeared to be scope and support for deeper north-south economic cooperation. Moreover, the sector is one of the six areas of cooperation specifically identified by the Belfast Agreement, which suggests that a relatively high degree of consensus exists for the development of cross-border tourism initiatives. Thus we 
selected a sector where positive conditions seemed to prevail for the testing of the propositions set out earlier with regard to cross-border cooperation.

A three pronged methodology was used to advance the investigation. One was the assembly of primary data from government statistics and industry sources. This was designed to place the sector in its wider economic context; to establish some of the key dynamics of the sector north and south of the border; and to assess the degree of convergence and divergence that exists within the industry on the island. Another prong was the conducting of semi-structured interviews with relevant policy-makers in numerous public agencies both side of the border as well as important business people in the sector. These interviews, which totalled 28, tended to focus on two matters. One is the extent to which policy questions have started to be considered jointly by the tourist authorities in each jurisdiction and whether issues have been identified as requiring a north-south co-operative resolution. The other is the scale and nature of interactions between participants: whether agencies and business organisations in each jurisdiction are interpreting sector problems in a similar fashion and how actors are changing established patterns of behaviour to develop meaningful cross-border collaboration. The final prong to our investigation involved reading relevant literature published by public agencies and other agencies to assess whether a discourse on north-south cooperation on tourism was entering into official documents on the sector.

\section{The tourism sector in the two Irish economies}

Tourism makes an important contribution to the Irish economy. In 2004, approximately 6.6 million overseas visitors came to Ireland generating about 4.1 billion euro in foreign exchange earnings. Overall, the industry had a turnover of about 5 billion euro. Approximately 230,000 are employed in the sector. While performance was good in 2004, the tourism sector has been going through quite a volatile period in recent years. After the mid- and late 1990s, which can be considered boom years for the industry (the sector contributed over 6 per cent to Irish GDP during this period) the sector experienced a slowdown (the sector on average has contributed 4 per cent to GDP between 2000 and 2004). Most of this slowdown can be attributed to Americans staying at home in the aftermath of September 11th.

The good 2004 performance appeared to signal a return to "business as usual" for the industry, but all the indications suggest that 2005 will be a poor year. This dip in activity has generated considerable concern within industry and government circles. A big debate has started in Dublin about whether the current agencies used to promote the industry are malfunctioning in one way or another. There has even been speculation about whether the traditional "Irish identity" used to encourage tourists to the country needs to be reinvented. As a result of this concern about the industry's performance, considerable policy action can be expected in forthcoming years to modernise the sector.

In Northern Ireland the tourism industry is much less developed because of years of conflict, although performance has improved since the first IRA ceasefire in 1994. Just over a million tourists visited Northern Ireland that year; however, this number 
increased to around 1.7 million in 2004. Employment in the industry has increased from 11,000 in 1994 to about 19,000 in 2003. Although the industry in the region has been growing in the past decade, so have other parts of the economy. As a result, the contribution made by tourism to regional income has remained more or less the same at about 2 per cent, much less than the 4 per cent figure for the south. Thus although there is satisfaction within the industry and government about the improved performance in recent years, there is still a widespread realisation that the sector is operating below maximum feasible potential. Recent pronouncements by the IRA that its war is finally over will improve the political environment for the industry. But there does not appear to be the same urgency in approach that can be detected in the south about whether the current strategies used to advance the interests of the sector need revision.

Beneath this aggregate picture there are important differences in the dynamics of the industry north and south of the border. The first and obvious difference is the much bigger size of the tourist market in the south than in the north. The number of tourists to the south outstrips the number for the north by roughly a factor of 3.5. Over ten times more people are employed in the industry in the Republic than in Northern Ireland. There is also a big gap in the level of tourist expenditure between the two economies. Tourists spent about 3.2 billion euro in the south whereas the equivalent figure for the north is about 400 million euro. The contrasting size of the two tourist markets is reflected in the accommodation available to tourists. In 2004 there were 131 hotels in Northern Ireland providing about 6,000 rooms for tourists whereas there was 846 hotels in the south offering a total of 43,000 rooms to the market.

Interestingly, the overall net number of hotels in Northern Ireland has only increased by seven since 1994, yet the overall number of available rooms has increased by 2,400 during the past decade. During the same period the overall number of hotels in the south increased by 140 , while the number of available rooms increased by 18,000 . This suggests that in the south there have been both new entrants into the hotel market and an increase in the capacity of established hotels, yet in the north market growth appears to have occurred largely by existing hotels increasing their capacity. Clearly entrepreneurs still regard investment in hotel capacity in the north as a big risk. Self catering accommodation is the market segment that expanded the most both in the north and the south in the past decade. In the Republic the number of self catering premises increased from 4,200 to 18,000 between 1994 and 2004 whilst the number grew from 266 to 700 premises in the same period in northern Ireland. The guest house/B\&B segment has experienced contrasting fortunes either side of the border over the past decade or so. In 1994, there were 150 (approved) guesthouses in Northern Ireland but by 2004 this had declined to 140. By contrast, the segment in the south experienced an increase from 327 (approved) guesthouses in 1994 to 460 ten years later. These figures not only confirm the contrasting sizes of the two markets, but also suggest that entrepreneurial activity in the south is significantly higher than in the north. 
Table 1: Country of origin of overseas visitors to Ireland in 2004

\begin{tabular}{|c|c|c|c|c|}
\hline \multirow[t]{2}{*}{ Origin } & \multicolumn{2}{|c|}{ Northern Ireland } & \multicolumn{2}{|c|}{ Republic of Ireland } \\
\hline & Number & $\%$ & Number & $\%$ \\
\hline Great Britain & $1,400,000$ & 81 & $3,700,000$ & 56 \\
\hline Other European & 133,000 & 8 & $1,600,000$ & 24 \\
\hline USA & 122,000 & 7 & $1,000,000$ & 15 \\
\hline Other & 70,000 & 4 & 317,000 & 5 \\
\hline Total & $1,725,000$ & 100 & $6,617,000$ & 100 \\
\hline
\end{tabular}

Differences exist in the market for international visitors either side of the border. Table 1 shows the country of origin of overseas visitors to Northern Ireland and the Republic of Ireland. The interesting point that arises from the table is the high concentration of visitors from Great Britain in the figures for Northern Ireland. Although the majority of overseas visitors to the Republic also come from Great Britain, the country is not as dependent on one country as the north. This suggests that the north still has an "image" problem to conquer, but if this can be overcome then there appears scope for the region to attract greater numbers from countries like Germany, France and the USA. Figure 1 compares where visitors stayed on arrival in the north and south respectively in 2004. It shows that 70 per cent of visitors to Northern Ireland stayed with friends while the majority of visitors to the south stayed in hotels. This suggests that the two parts of the island appeal to different segments of the market for international visitors. A further difference is the length of stay of international visitors in the two markets. On average, visitors stay for 10 days in the Republic while they stay for only 6 days in Northern Ireland. Thus, overall, visitors to the south are more likely to come from a wider range of countries, stay in hotels and for longer than in the north.

Aspects of the institutional structure that exists either side of the border to support the industry also display differences. In the Republic, the tourism federation body, the Irish Tourism Industry Confederation established in 1984, appears vibrant and

Northern Ireland

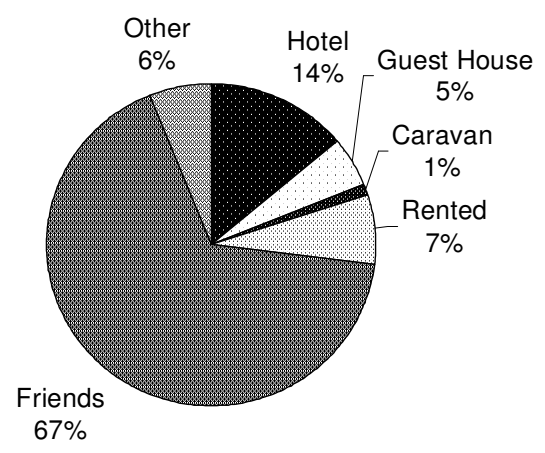

Republic of Ireland

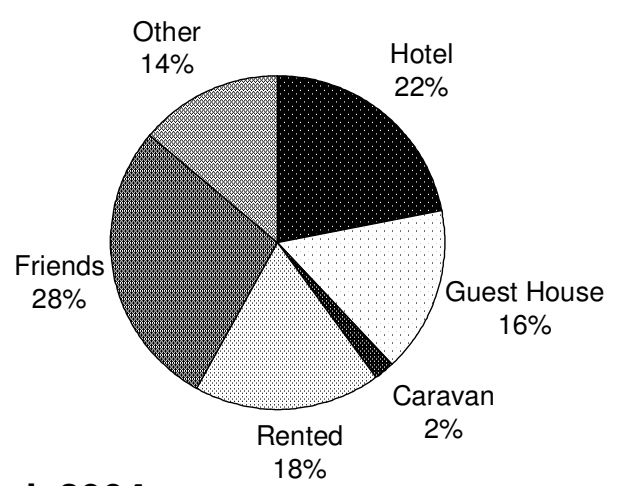

Figure 1: Where visitors stayed, 2004 
self-motivated. This body has membership from the major private and commercial state organisations such as Aer Lingus and Aer Rianta as well as the principal representative bodies in the Irish Tourist Industry including carriers, hoteliers, vintners, restaurateurs and visitor attraction proprietors. The equivalent tourism federation body in the north, Northern Ireland Tourism Industries Confederation (NITIC), was established in early 2003 and according to one interviewee from NITB "attempts to mirror the southern equivalent however appears to be bogged down in operational activity which has prevented it from looking at the future of the industry". Thus the stakeholder coalition that develops within a particular industry to advance its interests in the political and economic system appears stronger and more organised in the Republic than in the north.

This short review of the tourism industry in the two parts of the island shows that important differences exist in the structure, conduct and performance of the sector either side of the border. As a result, claims that the sector is ready-made for deeper cross-border cooperation initiatives should be treated with caution, despite the intuitive appeal of this position. At the same time, the counter position that the scale of the differences are such that insurmountable obstacles exist to creating better connections between the north and south on tourism should also be treated sceptically. It must be remembered that the dynamics of the tourism industry diverge considerably within each jurisdiction, but this does not rule out the pursuit of a unified tourism policy within each territory. In other words if the transaction costs associated with bringing the industry closer together can be successfully addressed then there is every chance of meaningful north-south connections opening up in the sector. But the review above suggests that the transactions costs are likely to be high and that addressing them will be complex. It is against this background that the analysis now turns to examine the progress that has been made on the matter.

\section{Progress towards north-south cooperation}

There is evidence to suggest that greater cross-border cooperation in the tourism sector has increased in recent years and that a number of interesting initiatives have been launched. Interactions between government officials involved in developing the tourism industry both sides of the border have increased after the signing of the Belfast Agreement. Evidence from interviews with representatives of the Department of Enterprise, Trade and Investment of Northern Ireland (DETINI) indicate that there is regular contact (six meetings per year) between DETINI and its counterparts, the Department of Tourism, Sport and Recreation, in the Republic of Ireland. Discussions revolve around macro strategic issues including for example, SARS, the impact of Foot and Mouth, inflation and standards. Both departments are involved in joint meetings with Tourism Ireland Limited every other month. ${ }^{2}$ This provides a forum for discussion and the exploration of emerging tourism issues.

\footnotetext{
${ }^{2}$ Tourism Ireland Limited is the cross-border, publicly owned, limited company established by the two governments as part of the Belfast Agreement, and tasked with promoting tourism to the island of Ireland.
} 
Progress has been made on defining the interface between each national tourism body and Tourism Ireland Limited. For example, in the Republic of Ireland work began in early 2003 to establish a new organisation, the National Tourism Development Authority, whose activities include "product marketing in partnership with Tourism Ireland Limited" and which will take responsibility for drawing up "memoranda of understanding between the new organisation and Tourism Ireland Limited and other bodies including Regional Tourism Agencies" (DAST, 2002). DETINI indicates in its operating plan for 2003-2004 that "we will work with Tourism Ireland Ltd to increase visitor numbers" (DETINI, 2003: 16), although they do not articulate how the relationship will develop in order to achieve such an outcome. However, memoranda of understanding between tourism agencies either side of the border have yet to emerge.

There is also evidence that the tourism bodies have identified similar matters to be addressed. In particular, both jurisdictions appear to be concerned with promoting better value for money, greater consistency of quality standards and good access to tourist locations. Thus, the NI Tourism Strategic Framework (NITB, 2001: 45) highlights the need to "improve access to Northern Ireland ... and ensure that tourism offers high quality experience and services to its customers" The Department of Arts Sports and Tourism in the Republic of Ireland identifies "fostering expansion and competition of access routes, supporting Tourism Ireland ... and a renewed emphasis on quality service and value for money" as key aspects of cooperation" (DAST, 2003: 13).

A study carried out in October 2002 by the Irish Tourist Industry Confederation (ITIC) suggests that "the national economic environment is becoming progressively less competitive due to high rates of Irish inflation relative to trade rivals coupled with adverse currency movements. In turn, this deterioration in national cost/price conditions is compromising the operating competitiveness of tourism" (ITIC, 2002). ${ }^{3}$ Although there is much concern that rising prices in Ireland are damaging the tourism sector, it is questionable whether this is a correct diagnosis of the most pressing problems facing the industry in the south (measured by the EU index Irish inflation in 2004 was $1.9 \%$ compared to the average of $2.1 \%$ ). Problems of greater magnitude are probably the virtual disappearance of the previous pool of domestic labour and serious skill shortages in some key areas. This is constraining the growth potential and the competitive performance of the industry more than price trends. Overall the focus of the pubic tourist authorities in the south is to improve, as one interviewee put it, "the quality of the Irish experience for international visitors". On the other side of the border, the Northern Irish Economic Development Forum (2003: 25) highlighted "improvement in the international competitiveness of indigenous Northern Ireland businesses (including tourism)" as a strategic priority to generate wealth. Thus the policy agenda for the industry is broadly similar. These common concerns present opportunities for both governments to work closer together to upgrade the tourism industry on the island.

\footnotetext{
${ }^{3}$ ITIC draws membership from private sector tourism players.
} 
A number of cross-border initiatives have been developed to address these areas of common concern. For example, NITB and Fáilte Ireland, the state tourism agencies in the north and south of Ireland respectively, are currently collaborating to ensure that the grading of hotels, B\&Bs and self catering accommodation is consistent in both parts of the island. Although each jurisdiction has its own accommodation reservation system, an information technology facility has been developed to link and integrate information from either system, thus ensuring consistency and validity of data. The two main training organisations for the industry, Tourist Training Trust in Northern Ireland and CERT in the Republic, are working together to develop crossborder training programmes. For example, cross-border projects have been allocated EU structural funds to provide training to tour guides in the Northwest area (which encompasses Derry and Donegal). High on the agenda of meetings between representatives from Department of Learning in Northern Ireland and CERT (which became an integral part of Fáilte Ireland in April 2003), is raising the profile of the industry to attract potential employees. Northern Ireland is the only area in the United Kingdom that has statutory regulation of the tourism accommodation industry. This regulation is aligned to that existing in the Republic of Ireland which has led to personnel from NITB and Fáilte Ireland carrying out standardised annual inspections and audits of all registered accommodation establishments on the island.

A range of cross-border tourism initiatives have been developed, centring around specific stand alone projects funded by short-term EU structural funds such as Interreg II, Interreg III and Peace II. While this extra source of funds is much appreciated by the industry, the tightly defined terms governing expenditure of this money limits the scope and thus the economic potential of some cross-border projects. For example, the Sustran (Sustainable Transport) project, which involved the development of a comprehensive cycle route straddling the border region, was funded to the tune of $£ 600,000$ by International Fund for Ireland and Interreg II; however, no further money was allocated to market the attraction or to employ representatives to promote it.

A similar proposal for developing disused railways throughout the entire North West region is currently seeking structural funding. The availability of structural fund money has also brought some notable successes. A cross-border car ferry set up between Magilligan in Derry and Greencastle in Donegal in 2001 has proved a highly successful venture for tourism in Greencastle, resulting in a marked increase in the number of providers servicing the tourism industry there. Interestingly, the impact on tourism on the other side of the border in Magilligan (Northern Ireland) has been marginal, with little evidence of private investors willing to develop businesses to service the tourist trade. It is hard to explain exactly why this is the case. One possible reason is the political history of the town (a prison ship was anchored off the town's coastline in the early part of the troubles). But the lack of development in Magilligan only reinforces the often-made comment that opportunities remain to further develop the tourism industry in the north.

Three cross-border local government networks (East Border Region, Irish Central Border Region and North-West Region) have been set up. Each network pursues a range of objectives, including tourism. Whilst individual councils make a financial 
contribution to fund the networks, it is access to EU or International Fund for Ireland funds that provides the motivation for the creation and sustaining of these arrangements. The activity of these networks has influenced public policy thinking on tourism in each jurisdiction. The National Spatial Strategy for Ireland (Department of the Environment, 2002) and the Regional Development Strategy for Northern Ireland (Department of Regional Development, 2001) have both highlighted the importance of effective cross-border co-operation between Belfast and Dublin and Derry and Letterkenny in order to exploit significant economic development opportunities, although specific cross-border tourism policy questions are not mentioned. The Northern Ireland government committed itself to developing a master plan for the Derry City Council area in an attempt to provide a coherent approach to regional development strategy of which tourism forms a significant part. At the same time, the Republic of Ireland's Border Regional Authority is separately looking at developing regional planning guidelines for implementing the National Spatial Strategy in the border region.

Interviews with policy officials established that the Special Olympics were an important landmark in co-operation between the main tourist boards on the island. The "Host Town Programme" supporting this project was organised on a north-south basis. A special committee was set up which liaised with departments north and south on this matter. The International Fund for Ireland provided financial support for athletes, and IFI in conjunction with NITB and Fáilte Ireland developed special promotional packs for all visitors to help market tourist attractions on the island. This activity enhanced relationships between NITB and Fáilte Ireland and fostered a greater willingness to collaborate on large scale sporting events as evidence by the (albeit failed) bid between Northern Ireland, the Republic of Ireland and Scotland to host the 2008 European Cup. The clear success of the Special Olympics holds important lessons for developing the tourist industry both north and south. In particular, "special interest" events, whether it be in sporting areas where Ireland enjoys a comparative advantage (for example, equine activities), or in the cultural or historical spheres in which there is considerable international interest in the Irish experience, could be used more extensively to attract tourism to the island. Customised packages not only connect with targeted groups, but also provide a focus for meaningful joint collaborations north and south of the border.

Thus strand two of the Belfast Agreement has led to greater cross-border activity on tourism. Tourism Ireland (the North-South body which promotes the island of Ireland internationally) has been set up although not without difficulties. For instance, a prolonged period of negotiation and conciliation was required before agreement was secured on contracts of employment and working conditions for staff employed by the new body (Agnew, 2002). But now that the body has been set-up the sector has been placed in the spotlight. Tourism federations, private interests (hoteliers, restaurants, themes parks) and local government bodies are collaborating more with each other. This assessment is in line with other evaluations that have been conducted on cross-border tourist activity post the Belfast Agreement. Thus, when reviewing the level of engagement between the two main tourist boards on the island, Greer (2002) suggests that the creation of all-Ireland marketing programmes has injected more urgency and led to more effective decision-making. However, Greer's 
research also points to concerns voiced by tourism interests in the Republic of Ireland who suggest that joint marketing programmes encourage tourists to travel into Northern Ireland, causing a change to the traditional pattern of tourist travel within Ireland, which may not always benefit the south. In other words, greater north-south cooperation may result in zero-sum outcomes, with the South losing more times than the north.

This last comment stands apart from many discussions about deeper cross-border cooperation in Ireland. Often it is assumed that deepening business cooperation between the two parts of the island will open up a virtuous circle of positive benefits both for the north and south. But even a cursory examination of the literature on the economics of integration shows that intensifying economic flows across borders is a dynamic and complex process. In particular, the standard view is that whilst deeper economic/ business connections across borders have welfare enhancing effects at the aggregate level-improved competitiveness, more jobs and so on-it can spell bad news in certain instances at the micro-level due to restructuring and rationalisation programmes that arise from the collaboration or integration process. Thus it is perfectly possible for closer cross-border tourist cooperation to have an overall positive impact even though may be certain instances when the impact will be negative.

\section{Cross border tourist initiatives: more breath than depth?}

Overall, the Belfast Agreement has opened up an all-island dimension to tourism, but a question mark hangs over the "depth" of cross-border initiatives that have been set up and the extent to which all-Ireland tourism initiatives are influencing the core strategic activities of the main tourist bodies north and south of the border. There appears to be an absence of an integrated strategic plan for tourism on the island. NITB's Corporate Plan 2002-2005 (NITB, 2002a) makes no reference to cross-border tourism. Similarly, neither the 2003 Review nor the 2004 Outlook of Fáilte Ireland (Fáilte Ireland, 2003a) or the Report of the Tourism Policy Review Group (Fáilte Ireland, 2003b), published in September 2003, makes any reference to developing tourism in the Irish border region. Moreover, tourist boards and tourism sector federations in each jurisdiction tend to be quite protective of their respective tourism data. For example, there is little evidence that Fáilte Ireland and NITB share information on "spend per visitor" and other sensitive information. A further problem is that no framework exists to foster cross-border planning. Consequently procedures to advance speedy cross-border tourist connections are underdeveloped.

Interviews with officials about cross-border structures and interactions on tourismrelated activity correspond with this assessment: as one put it "each area is doing their own thing". Mr lan Skewis, an advisor to the Northern Ireland Assembly's Tourism Inquiry 2002, highlights in a discussion paper to the inquiry, the need to address "conflicts in strategy between NITB and Bord Fáilte" (Skewis, 2002: 18). But these conflicts of interest will not be easily ironed out as these only mirror contrasting market conditions. Thus, for example, in the north the private sector remains more dependent on grant aid than in the south (Invest NI, 2003: 6). The public sector is still the primary provider of tourist information and support services, which is in con- 
trast to the situation in the Republic of Ireland, where private operators deliver a whole range of tourism services including tourist information, visitor attractions and tours. With Northern Ireland enjoying an uneasy peace it is understandable that the public sector will have a greater "hands on" tourism provider role than would be expected in times of "normality". But one unintended consequence of this situation is that it could stunt the growth of the private sector tourist support industry. Paradoxically although the public sector has a strong presence in tourism support one worker in the field commented: "there are no funding incentives available for these (non-accommodation) investors to encourage risk taking". ${ }^{4}$

The issue here is that the design of public grant schemes to the tourism industry will require careful scrutiny as Northern Ireland moves closer to a fully peaceful situation. The deadweight and displacement effects that can be associated with public grant or subsidy regimes must be kept to a minimum. ${ }^{5}$ This is not an argument for the withdrawal of public sector funding for the tourism industry in Northern Ireland. The industry in the region will require sustained public sector support for some time to come, but this intervention needs to be smart so that it enhances and adds to private sector activity in the area. On this issue, the south is more ahead of the game than the north: thus each policy-making community is facing contrasting policy agendas, even though there appears to be convergence in broad policy goals. As a result, the scope for meaningful strategic interventions may not be as wide as many assume.

Thus, while our research indicates that greater cross-border cooperation has occurred on tourism since the Belfast Agreement, this activity has been constrained by the traditional territorial divide and differential rates of performance. Little evidence exists to suggest that the Belfast Agreement has brought about a "joined up" approach to tourism development on the island. At the micro-level, for example, tourism players are competing against each other to develop and deliver the most attractive tourism packages. These competitive players assemble along traditional north-south territorial divisions, divisions which are reinforced by the existence of different institutional arrangements, different rules and different sector conditions, which ultimately make it difficult for agencies and businesses in each jurisdiction to interpret and address sector problems in a similar manner.

\section{THE NORTH WEST AIR ACCESS INITIATIVE}

To gain greater insight into the potential and limits of developing cross-border initiatives between the various tourism players on both sides of the island we examined developments in the North West border region. Tourism in this area is relatively underdeveloped, particularly from the northern Irish perspective, and has been a victim

\footnotetext{
${ }^{4}$ Interview with Economic Development Officer, Derry City Council, Nov. 2003.

${ }^{5}$ Deadweight raises concerns whether the funded scheme would have happened in the absence of a public subsidy. Displacement is about the situation where the public subsidy enhances the market position of one organisation but has direct and possibly indirect negative effects on other organisations, causing the overall net impact of the subsidy to be small.
} 
of market failures brought about by poor cross-border tourism links, misalignment of spatial planning and economic development in the region and separate brand identities. Since the late 1990s attempts have been made to address this situation. Perhaps the most high profile initiative that has been launched is the North West Air Access Initiative.

The peripheral location of the region is widely considered to be the main obstacle holding back the local tourism industry. Derry City Council (in Northern Ireland) suggested that this weakness could be addressed by developing Derry City airport. This proposal gave rise to the North West Air Access Initiative, which was launched in early 1999. The idea gained the backing of the two state tourism agencies (NITB and Fáilte Ireland) and Donegal County Council (Republic of Ireland) as well as various other tourist agencies, including the Derry Visitor and Convention Bureau and North West Tourism. These various agencies formed the North West Air Access Consortium to promote the idea. The primary objectives of the Consortium were "to agree an air access marketing programme which will expand current airline services at the City of Derry Airport and will attract new airlines to the North West Region and agree a marketing programme which will facilitate the introduction of new air access routes to the region" (NITB, 2002b). The consortium was particularly focused on accessing structural funds through the EU Peace 2 Programme 20002006 to finance its various activities.

While the consortium itself had no private sector membership, it was keen to engage with private business organisations, such as Ryanair, primarily because attracting private sector investment was seen as critical to the success of the project. Thus, the consortium has the features of a worthwhile cross-border initiative. Most, if not all of the relevant stakeholders are included in one way or another so much so that considerable effort and time had to be spent on obtaining a consensus amongst the many participants regarding the objectives of the proposal and an action programme. This suggests that building and managing cross-border initiatives is a complex and at times frustrating task. Despite these organisational complexities a range of activities has been pursued to promote the project. Money has been secured from EU Peace II funds. An air access officer has been appointed and is engaging with local hoteliers, tourist boards, Ryanair and other low cost carriers. In addition, various local publicity campaigns have been launched to increase public interest and to generate "buy-in" from the business community. These activities have been relatively successful. The big driver behind the consortium is Derry City Council. The council's finance department, for example, manages the financial affairs of the consortium. The air access officer appointed to deliver the day-to-day activities of the project and report progress back to the consortium on a monthly basis operates from Derry City Council premises. This is not an entirely altruistic move on the part of the council as it owns the airport and thus would directly benefit from any increase in passenger usage.

One of the strengths of the North West Air Access Initiative is its single-issue focus, which allows the project to be easily understood and to achieve good visibility. Moreover, the substance of the initiative was such that it was easy to obtain buy-in from a wide number of stakeholders either side of the border. But it became appar- 
ent very quickly that the project was being advanced in the absence of any deep strategic thinking on the development of cross-border tourism in the region. Thus although the National Spatial Strategy for Ireland (2002) and the Regional Development Strategy for Northern Ireland (2001) highlighted the importance of effective cross-border co-operation between such towns as Derry in Northern Ireland and Letterkenny in the Republic to exploit economic development opportunities, little detail was presented about how to advance this objective.

In this context, it is not surprising to find that while the government administration in Northern Ireland is committed to carrying out a master plan for the Derry City Council area, the Republic of Ireland's Border Regional Authority is at the same time developing regional planning guidelines to implement the National Spatial Strategy in the area south of the border. No framework exists to facilitate collaborative crossborder planning. As a result, there is no institutional mechanism to synchronise planning interventions on a cross-border basis. Thus, while there is evidence of engagement, there is little to suggest that Donegal County Council and Derry City Council have collaborated in any meaningful way to develop a cross-border tourism strategy for the sub-region. One Derry City Economic Development Officer commented, "the governments have the problem of getting the interface right between Northern Ireland Tourist Board and Fáilte Ireland. They also have the problem of getting the interface right between agencies in each jurisdiction at sub-regional level."

The absence of an effective overarching framework impedes the emergence of a vision to guide cross-border interactions. As a result, traditional territorial divisions still tend to influence the branding and marketing of the tourism product. Thus, Donegal and the Northwest region excluding the City of Derry are presented as one brand and Northern Ireland including Derry City as another. This suggests that high levels of engagement have yet to develop between tourism agencies across border regions. As one interviewee put it there is a "lack of clarity in Northern Ireland regarding when we need to stand by ourselves, and when we need to be integrated into the island". 6 Tourism Ireland, the new all-island institution for the industry, is too narrowly focused on delivering concrete marketing programmes to effectively challenge this weakness. In fact, one commentator suggested that "Tourism Ireland is still working on old administrative jurisdictional boundaries". ${ }^{7}$

The fallout from an underdeveloped institutional architecture to facilitate crossborder tourism is that projects like North-West Air Access Initiative fail to be regarded as a strategic priority by the mainstream tourist agencies either side of the border. Another way of putting this is that the initiative is being developed in the absence of any effective feedback loops. One optimistic representative from the consortium suggests that the significant gains attributable to the air access project, in terms of increased tourist traffic, increased tourist spend and increased levels of employment in tourism, up to 2006, will help leverage additional funds from both

\footnotetext{
${ }^{6}$ Interview with Northern Ireland Tourist Board representative, Nov. 2003.

${ }^{7}$ Interview with Economic Development Officer, Derry City Council, Nov. 2003.
} 
governments, and shift responsibility for funding from a local authority level to central government level. But if this benign scenario does not unfold and because the project is stand alone one must pose the question, what happens when Peace II funding runs out in 2006? This case-study suggests that developing a decisionmaking framework either to advance a proposal speedily or to rule it out as not viable has still to emerge.

\section{CONCLUSION}

The overall conclusion of this paper is that cross-border cooperation in the tourism industry has increased since the signing of the Belfast Agreement, but this has not led to a radical change in the business or institutional dynamics of the sector either side of the border. Progress has been made towards developing policy complementarity, but there are still significant gains to be captured in this area. Policy recombination has occurred but mainly on matters that do not touch the core strategic activities of the two tourist bodies. A certain level of policy entrepreneurship has taken place, but the room to carry out this type of activity appears limited and has occurred mostly at the level of local government. Thus the emergence of a genuinely all-island approach to tourism remains some way off.

If these conclusions are cross-referenced with the propositions put forward earlier in the paper we gain an insight as to why cross-border cooperation has not been more extensive. With regard to the principal-agent framework that was developed our research suggests that the institutional innovations introduced by strand two of the Belfast Agreement are not robust enough to develop a fully integrated approach to tourism on the island in the short and perhaps even the medium term. It is even open to question whether the new framework is sufficiently strong to launch sustainable collaboration measures that bring mutual gains to both parts of the island in the tourism sector on any systematic basis. One can speculate whether the institutional changes made reflect a set of political preferences on the part of the two governments to achieve a level of cross-border cooperation that is significant enough to ensure northern nationalist buy-in into the Agreement, but not large enough to build deeper forms of cooperation in the tourism industry, let alone the institutional foundations of an all-island economy.

In other words, the two governments (the principals) have successfully managed to oversee the creation of an agency structure (strand two of the Agreement) for the development of cross-border cooperation that has neither the authority nor capacity to launch far reaching initiatives. For example, it has limited power to agenda set or to frame policy discussions that may challenge established thinking or ways of doing things. The arrangements that have been set up are little more than information clearing houses or tightly ring-fenced administrative agencies. They certainly do not represent an embryonic governance structures for an all-island economy.

Thus the institutional design of the Agreement constrains policy entrepreneurship, policy recombination activity and even the search for policy complementary. Delegation is not strong enough to solve the problems associated with attaining meaningful 
levels of cross-border cooperation on a sustained basis. With the institutional arrangements lacking the capacity to steer or frame cross-border economic activity, it is the principals that effectively remain in charge of the process. This situation has given rise to joint-decision-making traps (Scharpf, 1988). Policy-makers in both jurisdictions appear locked into established domestic policy communities to the extent that they have not engaged in deep strategic thinking about how to cultivate a genuinely common all-island approach to the tourism industry. This is not the result of any political considerations: it is mostly due to contrasting market challenges in the tourist industry either side of the border. Thus, in the absence of a strong framing centre these domestic actors do not have the required level of incentives to depart from established practices. This explains why there have been so few substantive moves towards north-south cooperation in the tourism industry or in other economic areas.

It also explains why most cross-border initiatives take the form of single or limited issue projects. A feature of these initiatives is that they do not appear to touch the mainstream governance framework for the industry in either part of the island. The fact that a lot of these projects are dependent on "external" sources of funding such as EU Structural Funds rather than integrated into mainstream budgets only serves to reinforce this sense of detachment. The argument is not that these projects are creating few benefits. The reverse is usually the case. Many initiatives have established activities and events that make certain localities more attractive to tourists. Without EU funding a lot of these initiatives may not have seen the light of day. Rather, the argument is that because these initiatives have the status of being externally funded, stand alone projects, disconnected policy feedback loops might be emerging. When these initiatives reach the end of their short-term funding cycle they risk being closed because they are not part of mainstream policy programmes.

Recent announcements from the EU stating that its special Peace and Reconstruction Fund for Ireland as well as other Structural Fund money will continue ensure that many initiatives are not facing the immediate threat of closure. But the important point is that positive feed loops need creating for cross-border initiatives. In concrete terms this means a disciplined monitoring system being established to ensure that cross-border tourism projects, which are considered to be generating considerable value-added activity, can be integrated into mainstream programmes. This alteration does not require big political or policy moves by either government and could be comfortably achieved within the present institutional framework.

Changes to "close" policy feedback loops are likely to be the only revision to the current institutional character of cross-border cooperation in Ireland. By and large, present arrangements appear to enjoy wide support. There is no clamour from any constituency-political, business or civil society-to tamper with present arrangements. As a result, this assessment suggests that there is no integrated policy model emerging for the tourism industry on an all-island basis. The parties to the Belfast Agreement signed up to a "minimalist" institutional structure for the promotion of north-south integration and that is what is unfolding. 


\section{REFERENCES}

Agnew J (2002) "Tourism Ireland-a unique facilitation", Labour relations journal 1 (1): 6-9

Barnard, C (1948) Organisation and management. Cambridge, MA: Harvard University Press

Bradley, J and E Birnie (2001) Can the Celtic tiger cross the border? Cork: Cork University Press

DAST [Department of Arts Sport and Tourism] (2002) Establishment of new tourism development authority: report of implementation group. Available www.arts-sporttourism.gov.ie/pdfs/tda.pdf [2006-03-14]

DAST [Department of Arts Sport and Tourism] (2003) First statement of strategy (20032006). Belfast: Government of Northern Ireland

Department of Environment (2002) National spatial strategy for Ireland: people, places and potential, location of development policies. Available www.irishspatialstrategy. ie/NSSDownloads.shtml [2006-03-14]

Department of Regional Development (2001) Regional development strategy for Northern Ireland: shaping our future: Londonderry: regional city for the North West. Available www.drdni.gov.uk/Contman/includes/upload/file.asp?ContentID=417\&file=c_24 [2006-03-14]

DETINI [Department of Enterprise Trade and Investment] (2003) Operating plan for 2003 -2004. Belfast: Government of Northern Ireland

Fáilte Ireland (2003a) Review 2003 and outlook 2004. Available www.failteireland.ie/pub lications_archive [2006-03-14]

Fáilte Ireland (2003b) Tourism Policy Review Group: New horizons for Irish tourism: an agenda for action. Available www.tourismreview.ie/Tourism \%20Review\%20Report. pdf [2006-03-14]

Fung, A (2003) "Associations and democracy: between theories, hopes and dreams", Annual review of sociology 29: 515-39

Grahl J and P Teague P (1992) The big market: 1992 and the future of the European Community. London: Lawrence and Wishart

Greer, J (2002) 'Developing trans-jurisdictional tourism partnerships-insights from the Island of Ireland", Tourism management 23 (4): 355-66

Invest NI (2003) Venture capital strategy: venture capital our approach. Available www.investni.com/ini_venture_capital.pdf [2006-03-14]

ITIC [Irish Tourist Industry Confederation] (2002) The impact of tourism on the Irish economy, prepared for the Irish Tourist Industry Confederation by Tansey, Webster, Stewart and Company, Economic Consultants. Available http://www.itic.ie/res10.html [2006-03-15]

Krugman, P (1995) Development, geography and economic theory. Cambridge, MA: MIT Press

Maarten A, and H Wagenaar-Hajer, eds (2003) Deliberative policy anaylsis: understanding governance in the networked society. Cambridge: Cambridge University Press 
McCallum, J (1995) "National borders matter: Canada-US regional trade patterns", American economic review 85 (3): 615-23

Michie, J and M Sheehan (1998), "The political economy of a divided Ireland", Cambridge journal of economics 22 (3): 243-59

Nelson, R and S Winter (1982) An evolutionary theory of economic change. Cambridge: Belknap Press

NITB [Northern Ireland Tourist Board] (2001), Northern Ireland tourism strategic framework (2001). Belfast: NITB

NITB [Northern Ireland Tourist Board] (2002a) Corporate plan 2002-2005. Available www.nitb.com/article.aspx?ID=235 [2006-03-14]

NITB [Northern Ireland Tourist Board] (2002b) Submission document for Peace 2 Measure 5.2b. Belfast: NITB

Northern Irish Economic Development Forum (2003) Working together for a stronger economy. Available www.edfni.com/WTforaSE/fullreport.pdf [2006-03-15]

O'Leary, B (1999) "The nature of the agreement", Fordham journal of international law 22 (4): 408-33

Orszag, JM and DJ Snower (1998) "Anatomy of policy complementarities", Swedish economic policy review 5 (2): 303-45

Roberts, N and P King P (1996) Transforming public policy: dynamics of policy entrepreneurship and innovation. New York: Jossey-Bass

Scharpf, $F$ (1988) "The joint decision trap: lessons from German federalism and European integration", Public administration 66 (3): 239-78

Simon, H (1977) Models of discovery. Boston, MA: D Reidal Publishing

Skewis, I (2002) Workshop discussion notes: paper prepared to aid the Committee for Enterprise, Trade and Investment Tourism Inquiry. Unpublished document, Belfast 